\title{
Article
}

\section{Studying Employment Relations from a Trade Union Perspective: the Politics of Research}

\author{
Martin, William Douglas mitchell \\ Available at http://clok.uclan.ac.uk/24357/ \\ Martin, William Douglas mitchell ORCID: 0000-0003-4056-5869 (2019) \\ Studying Employment Relations from a Trade Union Perspective: the Politics \\ of Research. Sage Research Methods Cases.
}

It is advisable to refer to the publisher's version if you intend to cite from the work. http://dx.doi.org/10.4135/9781526478122

For more information about UCLan's research in this area go to http://www.uclan.ac.uk/researchgroups/ and search for < name of research Group>.

For information about Research generally at UCLan please go to http://www.uclan.ac.uk/research/

All outputs in CLoK are protected by Intellectual Property Rights law, including Copyright law. Copyright, IPR and Moral Rights for the works on this site are retained by the individual authors and/or other copyright owners. Terms and conditions for use of this material are defined in the policies page.

\section{CLoK}

Central Lancashire online Knowledge www.clok.uclan.ac.uk

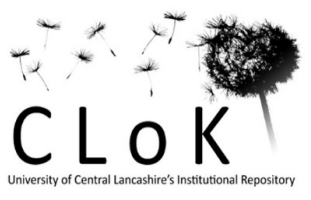




\section{Case Title}

Studying Employment Relations from a Trade Union Perspective: the Politics of Research

\section{Author Name}

Douglas Martin

\section{Author Affiliation and Country of Affiliation}

Lancashire School of Business and Enterprise, University of Central Lancashire, Preston, UK

\section{Lead Author Email Address}

wdmmartin@uclan.ac.uk

\section{Discipline: D12}

Sub-discipline within Business and Management

Employment Relations

Academic Level of intended readership

Postgraduate and doctoral researchers

\section{Contributor Biography}

Douglas Martin is a Senior Lecturer in Human Resource Management at the University of Central Lancashire. He completed his $\mathrm{PhD}$ research at the University of Strathclyde into lean and the trade union response. Douglas had previously spent around 20 years working in the Civil Service. He was active in his trade union at national and local level particularly in the area of health and safety serving latterly on the staff side of a national departmental safety committee. He currently works at the University of Central Lancashire where he is course leader for the Human Resource Management undergraduate degree programme. He teaches on several undergraduate and postgraduate modules. Douglas also holds supervisory responsibilities at doctoral level.

\section{Published Articles}

The following articles have recently been published using data from his research into lean and the trade union response:

- Martin, D., (2017). 'Lean' in the UK Civil Service: from the theory of improvement to the varied realities of cost cutting. La Nouvelle Revue du Travail, 10, doi: http://10.4000/nrt.3117

- Martin, D., (2017). Making tax and social security decisions: lean and deskilling in the UK Civil Service. New Technology, Work and Employment, 32, 146-159, doi: http://10.1111/ntwe.12092 


\begin{abstract}
The case study examines the politics of research. The case study deals with a research project looking at the implementation of lean working in the UK Civil Service and the trade union response. The study will assist those researching trade unions and employment relations to conceptualise the politics of research. The case study is based on the author's PhD. The article describes the potentially robust collaboration between the author and the union at the outset of the project contrasting this with the frustrations and opportunities generated by the ways the union did not support the research as the author had anticipated. Recognising that the union seemingly placed limited value on the research process, the author adopted his research methods pragmatically. The author recommends that researchers use union structures to acquire legitimacy to gain access to union stewards and members. He provides suggestions on how this might be achieved particularly for researchers with a limited trade union background. The case study concludes with questions for reflection.
\end{abstract}

\title{
Learning Outcomes
}

This case study will help postgraduate and doctoral researchers who are intending to undertake research into employment relations from the perspective of trade unions. The case study has wider implications as it will assist researchers to reflect on the politics of research; how organisations may seek to influence the research process; and how researchers can obtain valid academic outcomes.

Specifically, the case study will allow researchers to learn to:

- Conceptualise the politics of research in the context of trade unions, but also more widely in researching other organisations

- Recognise how the internal politics within an organisation may influence or impact the research process

- Adapt research methods to respond to these constraints placed on researchers

\section{Introduction: The Research Problem}

The issues highlighted in this case study address some of the challenges in undertaking research within the trade union side of employment relations. The case study provides the opportunity to examine how the politics of research influence and define the ways in which research is carried out. The case study will examine how the politics of research affects the collection of data from a trade union and its members.

My doctoral research examined the use of lean working within the UK Civil Service focusing on how lean working affected employee skills. It also examined the response of the trade union.

Lean is a business improvement method popularised through its use in automobile manufacturing. Lean seeks to eliminate waste by the more effective use of all resources including better use of the workforce using employees' knowledge and skills as a means of continuous improvement in the production process (Holweg, 2007). Using some of the 
lessons from manufacturing, the public sector has made extensive use of lean. Public sector management holds the view that lean has the potential to reduce costs and use its workforce more efficiently, critical issues during a period of government fiscal austerity (Radnor and Osborne, 2013). Its use within the Civil Service has been the source of conflict between management and the trade union due to the union's concerns about work intensification and deskilling of its members (Carter et al., 2011). The Public and Commercial Services Union (PCS), the main Civil Service trade union, presented an ostensibly oppositional stance to lean (Gall, 2007). Nonetheless, opinions within the union regarding the national union's handling of lean were divided. A study by Carter et al. (2012) highlighted how grassroots members believed that the union leadership had engaged in a form of collaborative working with management compromising the militancy of the union activists operating in local branches. My research allowed an examination of the trade union response to lean in an environment where the union views were not homogenous.

These diverse views reflect the nature of trade unionism where militancy and moderation can co-exist across the spectrum of a single union (Kelly, 1996). Unions are composed of a 'variety of fragmented employee groups' (Hyman, 1975:41) divided by ideology and role within the organisation. Even within individual unions, there can be elements of militancy and moderation with members, activists and those in senior positions, both elected officials and paid employees, having divergent views.

Although my research focussed on employment relations and the implementation of lean working, this case study has wider application. This case study will allow researchers to reflect on how different perspectives within a single organisation can influence the research process. It also brings to the fore how any organisation might exert power to influence research to promote a dominant view. One way to understand this process is by examining the politics of research.

Hammersley (2000) addresses the politics of research in terms of three elements. First, he defines the politics of research as the exercise of power in the research process. In most business and management research, the researcher's power is significantly constrained by the organisation that commissions the research. Despite the conceit of believing that the researcher may have some privileged position in understanding the nature of the organisation, access is always more limited than researchers would wish. On the one hand, an organisation may seek to guide researchers in a particular direction to help them get the best out of the data. On the other hand, gatekeepers may wish to hide those aspects of the organisation that do not fit with its public persona. For trade unions, it may involve presenting a persona to both its members and to the employers with which it has to negotiate, ostensibly to indicate a trade union united in purpose and strength.

The second aspect of the politics of research relates to the value judgements held by the organisation and its members. Conventional business research has the tendency to assume a value-neutral role for research and its outcomes. A common assumption is that the resolution of a business problem can achieve positive outcomes for all parties in the organisation rather than recognise that different groups of people do not share common views or beliefs. At its 
most extreme, people may be diametrically opposed to each other in terms of their values or perspectives about the organisation.

The third element relates to the actions taken by an organisation arising from these value judgments. Research can be undertaken pragmatically seeking to resolve a specific organisational problem (Ghauri and Grønhaug, 2010). However, while the parties in the research may be driven by pragmatic considerations, it should also be acknowledged that unspoken value judgements may influence how the research is carried out and ultimately how the findings are presented within the public domain.

Among the challenges faced by researchers is that the internal politics of a union may involve 'gaming' particularly where elected officials may seek to position themselves in such a way that it secures their status among the membership (Huzzard and Björkman, 2012). This gaming may not be apparent to an external researcher. Added to which, trade unions when commissioning research have not traditionally been concerned with the methodological issues that underpin the research methods. Their concerns have often been with obtaining data to support a pre-existing view, but not with the process of research. As Huzzard and Björkman (2012) observe, the impact may be seen in the amount of time and resources a union will allocate to the research process. The researcher may be faced with an expectation that the union believes that the research outcomes are self-evident and that the data collected will confirm what the union already holds to be true. The value judgments with which researchers need to contend are not only ideological beliefs about the substantive issues under investigation, but also about the value of the research process.

In the case study, I will outline the initial design of the research project and discuss how the research had to be modified to reflect the politics of research within the union. My experiences aim to help other researchers reflect on how best to adapt their approach to the study of employment relations. I have provided some final questions for reflection and to stimulate debate.

Due to space limitations, I am unable to discuss how I addressed the constraints placed on the research by Civil Service management. My hope had been to collect data from management sources. However, the Civil Service has historically been very reluctant to allow outsiders access (Hunt and Chapman, 2006). I was unable to collect data from management and there were a significant number of constraints placed on the trade union members and stewards. However, how a researcher might deal with the politics of research in this area merits fuller consideration than can be given here.

\section{The Research Design}

My interest in exploring the use of lean in the Civil Service derived from my time working in one of the larger government departments and my experience as a union member and steward. The second inspiration for the research was the concerns of PCS about lean and its impact on work intensification and deskilling. The union had previously commissioned research on lean and had posited an oppositional stance (Gall, 2007). The research arose out 
of discussion between PCS, my primary academic supervisor and I. PCS agreed to support the project into lean over a three year period.

There was a useful degree of congruence between myself as researcher and the union in that I was sympathetic to the aims of PCS. Although lean had been brought in after my time in the Civil Service, I was sufficiently familiar with the types of work pressures experienced by union members and stewards. I was also familiar with the culture of the union and employment relations within the Civil Service. These factors allowed me an insight into the context of the research topic.

In terms of $\mathrm{PhD}$ supervision, the approach was interesting. Supervision was to be shared between my academic supervisory team and a senior union official. This had the potential to provide both academic rigour but also legitimate my access to different tiers of the union, including paid officials, branch committees, local stewards and members. The aims for the project agreed by both parts of the supervisory team included researching the impact of lean and how the PCS had responded to lean. Some of the initial suggestions were that I locate myself not only at the university, but also at the local union office (one day a week was mooted) which I could use for research interviews. This approach meant potentially that two of the main barriers to research, lack of clear aims and poor access to data respondents, would be overcome at an early stage of the project.

In terms of methods, I agreed with the supervisory team I should use a mixed methods approach consisting of a survey of members and semi-structured interviews of union stewards and members. With the Civil Service comprised at that time of around 330 separate departments, it was impractical to research every department. It was agreed that I focus on a small number of departments where lean had been used.

The initial phase of the research involved making contact with a number of senior officials in different PCS Groups to gather an understanding of the main issues. The structure of PCS largely mirrors Civil Service organisation with members allocated to Groups depending on the department for which they work. Each Group has its own branch structure. My approach was to identify senior branch officers in several of these Groups. I contacted a number of PCS officials through a combination of using pre-existing personal contacts, names of people provided by the union, or the PCS website to identify senior paid members of PCS staff. My intention was to identify individuals within the union who by reason of their position had knowledge of the implementation of lean and who could act as gatekeepers to the various tiers of the union.

\section{Changes in the Research Process}

From the outset of the research, there were a number of challenges to be overcome, the first relating to the role of the national union, and the second relating to collecting data at local level.

Attempts to work with the national union were frustrating. Despite the promising supervision structure, once the project was set in motion, the national union maintained a very hands-off 
approach. Meetings with the union supervisor were rare and I received very little feedback on my progress with the research. After considerable prompting, the union supervisor circulated emails to other senior officials reminding them to promote the research within their areas of responsibility. However, no direct benefit arose from this action. The hope that I could use a local union office was also dashed as I was advised that there was insufficient space in the office to accommodate me albeit I could still use it for interviews on an ad hoc basis.

Although a plausible reason for not providing facilities, it was suggested to me by a PCS steward of my acquaintance that certain parties in the union did not want 'an outsider' working in the office who would be privy to PCS business. Ultimately using the national union as a route into the research was closed when in the final year of the three year project I was advised by the union supervisor that any previously agreed approaches could not be honoured as the union was now engaged in other important campaigns.

Using contacts at a Group level was equally problematic. Although senior Group officials were often willing to provide a preliminary interview, the first major challenge was that having done this, their role as gatekeepers was limited to providing names of individuals. It did not involve actively facilitating access by, for example, contacting those individuals on my behalf or arranging interviews. Their gatekeeping role was largely one of providing legitimacy to the research, but the responsibility for contacting branch officers was devolved back to me. No Group official contacted me to find out if I had been successful in making contact with branch officials. Once branch officials had been contacted, it proved problematic to get any form of effective follow-up. There was a significant amount of ostensibly wasted time waiting for people to reply to emails or telephone calls. In one instance, a senior branch official told me that members "would be queuing up to meet with you", yet after 13 months of intermittent contact, I was unable to make any progress on this initially promising opening. In this case, the reasons for the delay were initially that the research had to be approved at branch level. This avenue was finally closed off when this individual advised me that the branch was too busy in negotiating with management over a major internal restructuring, ironic since my research related to the effects of the restructuring of work.

Having realised that reliance on more senior PCS officials to facilitate access to lower tiers of the branch union structure would not generate a sufficiently robust sample, I adopted an "opportunistic" approach to the collection of data (Buchanan et al., 1988). Due to the restrictions imposed by Civil Service management on the distribution of survey forms to PCS members in work time, my approach was now to rely wholly on semi-structured interviews. Provided branch officials were aware of the research, some of whom were personal contacts, I had effectively carte blanche to interview any steward or member willing to participate using whichever methods I deemed appropriate. Many of the interviewees were approached as a result of attending branch and other union meetings, often ones to which I had pressed for an invitation. I used these meetings to explain the research and invite participants to "sign up'. Interviews were arranged using mutually convenient locations and times. Civil Service management provide stewards with an allocation of time for trade union duties and activities. A proportion of the interviews with stewards were therefore conducted in work hours using this 'facility time', but other interviews were also after work in a social setting. Interviews 
were done face-to-face, in groups or over the telephone. Contact with PCS members used a similarly opportunistic approach using personal contacts and snowballing to get additional names. Members did not have the facility time available to stewards and their interviews were conducted in their own time after work. I ostensibly had the legitimacy of the union to support the research, but in reality most of the interviews would not have progressed without previous personal contacts, or through my initiative in attending union meetings.

\section{The Politics of Research}

Recognising the value judgments that the union made about the content of the research and the research process allowed me to modify my approach during the currency of the project.

Preparation for my field work was underpinned by a literature study of Civil Service Unionism. I also had the advantage, not necessarily open to other researchers, in that I knew the sector and I had a familiarity with the culture of the Civil Service and the union. However, it was only during the currency of the research project that I began to fully appreciate how the politics of research influenced the direction of the study. As a relatively recent insider to the union, I had assumed the degree of congruence between myself and the union over the aims and objectives of the project would greatly improve the level of access to a number of PCS Groups. The amount and level of access proved to be significantly different to what I expected.

On reflection, it was apparent that the union's value judgements about the aims of the research influenced the direction and urgency with which it supported the project. The union's judgements about the value of evaluating lean were an important factor when it commissioned the research project. Without a belief in the utility of the likely outcomes, it is unlikely that support and access would have been provided. However, the judgements made by the union about the research process and methods used to collect data were as significant in determining how PCS supported the study.

It would be fair to say that the union commissioned the research because senior union officials believed there was value in obtaining research to combat some of the ways that the Civil Service was implementing lean. For the union there was also merit in evaluating how collectively the stewards and members were responding to management at a workplace level. The risk for PCS was that at a workplace level those views would not match the views of the national union. In reality, stewards and members shared many of the concerns of the national union. Where they differed was in terms of their view of the role of the union. They were often less optimistic about the capacity of the union to challenge the negative effects of the implementation of lean and were often critical of the apparent compromises made by the union negotiators at national or Group level.

On one level, I have might have expected the union to steer me away from discordant views. The decision to deny office space may reflect that. However, the more significant issue was the lack of interest in the value of the research process. The research project was generally seen as a 'good thing', but I sensed that PCS believed the research outcomes were so selfevident that little more than some preliminary discussions with lead negotiators would give 
the union the results they desired. Any time or energy expended on securing rich data from the stewards and members was seemingly given little priority. These same value judgements were often mirrored at Group and branch level.

Recognising how the value judgements affected the process research was a reflective process. I needed to reflect on such key issues as:

- Why did the union commission the research? (And then do little to progress the project?)

- Did PCS understand what academic research involves?

- How much significance did my status (in my case, an informed outsider) have in securing access to different tiers of the union?

Researchers should asking be asking themselves similar questions. With funding for academic research at a premium in the modern university environment, there is a temptation to take any opportunity that arises. Researchers should always give careful thought before commencing any research to ensure that there is a significant degree of congruence between the researcher and the organisation in the value placed on the research process. Moreover, researchers also need to carefully consider whether the commissioning organisation might try to steer the project in a direction by which its academic integrity might be lost or compromised.

My status as a recent insider was a significant advantage in recognising some the issues involving trade union research. For the outsider researcher, establishing credibility in the minds of the main gatekeepers is critical. Identifying a sympathetic branch union official who can provide introductions is important. In trade union research, giving branch officials "their place" implies respect for the union structures. Attending union meetings and liaising with union stewards in a social setting may be as useful as the conventional interview setting in achieving this credibility.

The challenge for the outsider is to distinguish between gatekeepers who may be willing to provide useful preliminary information and those who will be more active in facilitating access to stewards and members. The process is both frustrating and liberating. It is frustrating as the constant process of renegotiation may result in a number of false trails as gatekeepers may fail to see the value of the research. It is also liberating in that once researchers have found an avenue into the research, it allows them to source participants. As many outsider researchers will lack personal contacts, they continually need to maintain the process of establishing credibility with stewards and members. As stewards' gatekeeping will likely be more about providing introductions to individuals or invitation to union meetings, it does allow researchers to source participants with a broader range of views. Researchers will often find interviewees who may express discordant views about senior tiers of the union and their handling of employment relations. Locating discordant voices may be a significant indicator in assuring researchers that their study is achieving an appropriate degree of academic integrity. 
Personally, once I recognised that using the union hierarchy would not provide me with a sufficient number of interviews, I took a more opportunistic approach. The structures were useful to the extent that they allowed me to increase my credibility with the union, particularly in those areas where I lacked personal contacts. I used the union's value judgement that the research had worth, but I had to be pragmatic in terms of recognising the union's limited level of interest in the process of research. In reality, I needed to be seen using the structures primarily to validate my research in the minds of the participants.

To what extent the union would have continued to support the research had the participants continued to voice their criticism of the union's approach to lean is a moot point. The data that I collected was valuable in academic terms. However, despite my offer to present the findings at branch meetings, the union did not ask me to present the findings more widely. I was told that in one of the preliminary meetings that some of the reluctance by PCS members to participate was borne of the fact that previous similar studies had not resulted in any positive workplace improvements for staff. The issue of how findings are disseminated requires fuller treatment that can be given here, but this lack of interest in getting my research communicated to a wider audience may again reflect the level of value that organisations, particularly unions, accord academic research.

\section{Conclusion}

Much of the literature surrounding access to organisations concentrates on the role of gatekeepers, individuals who control access to the organisation (Saunders et al., 2016). Issues of perceived value, sensitivity and the researcher's credibility with the organisations are important issues that help facilitate access. There is a need to constantly renegotiate access at different levels of the organisation, using both the formal structures and informal contacts (Reeves, 2010). There is also the possibility that gatekeepers, despite the public face of the organisation, may (by intent or otherwise) obstruct the research (Punch, 1986).

Each of the above issues is relevant to union research and employment relations research more widely. However, this case study reminds the outside researcher to reflect on the likely value that a union will place on the research and the research process, and how the politics of research affects the way that a union supports academic studies. Recognising how union branch structures provide an avenue to find people willing to participate in the research is central to research in this area. Provided researchers pragmatically adapt their approach, use personal contacts provided by supportive branch officials and maximise social settings, there are significant opportunities for the collection of rich data.

\section{Discussion questions}

1. My research was done ostensibly an as informed outsider. Researchers may come to the area of employment relations without necessarily having a trade union background. For researchers in this situation, what practical steps might they take as outsiders to gain access to union structures?

2. How might an organisation use the 'politics of research' to influence a researcher to produce the results it wants? How can researchers mitigate the effects of an 
organisation wanting to reach what it considers self-evidently obvious research outcomes?

3. What advantages and disadvantages would someone gain from researching employment relations and trade unions as an insider (for example, as an active union steward)? Would that make that individual more or less susceptible to the politics of research?

\section{References}

Buchanan, D., Boddy, D. \& McCalman, J., (1988). Getting in, getting on, getting out, and getting back. In Edited by: A.Bryman, (Ed.), Doing Research in Organizations (pp. 53-67), London: Routledge.

Carter, B., Danford, A., Howcroft, D., Richardson, H., Smith, A. \& Taylor, P., (2011). Lean and mean in the civil service: the case of processing in HMRC. Public Money and Management, 31, 115-122, doi: http://dx.doi.org/10.1080/09540962.2011.560708

Carter, B., Danford, A., Howcroft, D., Richardson, H., Smith, A. \& Taylor, P., (2012). 'Nothing gets done and no one knows why': PCS and workplace control of Lean in HRM Revenue and Customs. Industrial Relations Journal, 43, 416-432, doi: http://dx.doi.org/10.1111/j.1468-2338.2012.00679

Chapman, R. A. \& Hunt, M., (2006). Open government in a theoretical and practical context. In Edited by: R. A. Chapman and M. Hunt, (Eds.), Open Government in a Theoretical and Practical Context (pp. 139-147). Aldershot: Ashgate.

Gall, G., (2007). Lean and Job Design. PCS: London.

Ghauri, P. \& Grønhaug, K., (2010). Research Methods in Business Studies. Harlow: Prentice Hall.

Hammersley, M., (2000). The Politics of Social Research. London: Sage.

Holweg, M., (2007). The genealogy of lean production. Journal of Operations Management, 25, 420-437, doi: http://dx.doi.org/10.1016/j.jom.2006.04.001

Huzzard, T. \& Björkman, H., (2012). Trade unions and action research. Work, Employment and Society, 26, 161-171, doi: http://dx.doi.org/10.1177/0950017011426314

Hyman, R., (1975). Industrial Relations: A Marxist Introduction. Basingstoke: Macmillan.

Kelly, J., (1996). Union militancy and social partnership. In Edited by P. Ackers, C. Smith and P Smith, (Eds.), The New Workplace and Trade Unionism (pp. 77-109), London:

Routledge. 
Punch, M., (1986). The Politics and Ethics of Fieldwork. London: Sage.

Radnor, Z. \& Osborne, S., (2013). Lean: A failed theory for public services? Public Management Review, 15, 265-287, doi: http://doi/abs/10.1080/14719037.2012.748820

Reeves, C. L., (2010). A difficult negotiation: fieldwork relations with gatekeepers. Qualitative Research, 10, 315-331, doi: http://dx.doi.org/10.1177/1468794109360150

Saunders, M., Lewis, P. \& Thornhill, A., (2016). Research Methods for Business Students $\left(7^{\text {th }}\right.$ edition). Harlow: Pearson. 